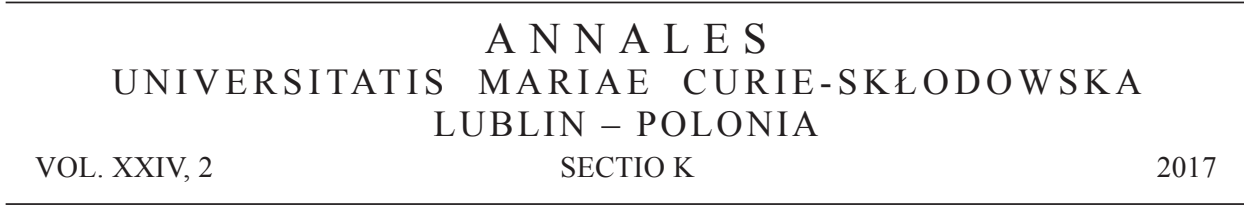

Instytut Europeistyki Uniwersytetu Jagiellońskiego w Krakowie

PAWEŁ KUBICKI

\title{
Od miejskiego aktywizmu do miejskich ruchów społecznych
}

From Urban Social Activism to Urban Social Movements

\begin{abstract}
Abstrakt: W artykule przeanalizowano proces tworzenia miejskich ruchów społecznych w Polsce. W pierwszej części autor przedstawił krótki historyczny rys kształtowania się europejskich miejskich ruchów społecznych oraz zmiany strukturalne, jakim są one obecnie poddawane. Drugą część poświęcono specyfice miejskiego aktywizmu w Polsce. Autor przeanalizował procesy, w których ramach rozproszony miejski aktywizm skutkiem wewnętrznej integracji ewaluował w kierunku miejskiego ruchu społecznego, reprezentowanego między innymi przez takie organizacje, jak Kongres Ruchów Miejskich czy koalicja wyborcza Porozumienie Ruchów Miejskich.
\end{abstract}

Słowa kluczowe: ruchy społeczne, ruchy miejskie, miasto, miejskość, Polska

\section{WSTĘP}

Proces kształtowania się miejskich ruchów społecznych jest jednym z ciekawszych zjawisk, jakie można obserwować w ostatniej dekadzie w polskich miastach. Jest to jednak fenomen stosunkowo nowy i nie doczekał się pogłębianych badań nad całokształtem specyfiki tego zjawiska. Głównym celem prezentowanego artykułu będzie analiza procesu krystalizacji tożsamości polskich ruchów miejskich, który rozpoczął się początkiem drugiej dekady XXI wieku. Materiał do analizy uzyskano głównie dzięki obserwacji uczestniczącej, a także analizie materiałów zastanych. W prezentowanym artykule starałem się uchwycić najistotniejsze prawidłowości, które pozwalają na integrację wielu rozproszonych inicjatyw obywatelskich w zjawisko, które można opisywać w kategorii ruchu społecznego, mając przy tym świadomość, że taki opis nie wyczerpuje całego złożonego problem polskich ruchów miejskich i do ich pełnego opisu jest konieczne przeprowadzenie badań szczegółowych. 


\section{MIEJSKIE RUCHY SPOŁECZNE. GENEZA}

Miejskie ruchy społeczne są jedną z form ruchów społecznych, zatem ich genezy należy poszukiwać w przemianach społecznych wywołanych dziewiętnastowieczną modernizacją i urbanizacją. Rewolucja przemysłowa, która zapoczątkowała intensywny proces urbanizacji, jak każda gwałtowna zmiana przyniosła z sobą także wiele negatywnych konsekwencji. Reakcją na nie była między innymi mobilizacja w ramach ruchów społecznych. Studia nad ruchami społecznymi - jako czynnikiem dynamizującym strukturę społeczną - stały się istotną częścią badań socjologicznych. Konsekwencją tego jest między innymi fakt, że w tym wypadku mamy do czynienia $\mathrm{z}$ wieloma różnymi teoriami. Zwracał na to uwagę Maciej Kowalewski, pisząc, że wpływ orientacji teoretycznej, w której ramach są podejmowane studia nad ruchami społecznymi, jest decydujący dla zdefiniowania tego pojęcia. W przeglądowych ujęciach rozwoju teorii ruchów społecznych wskazuje się na następujące kierunki badań, podejścia analityczne i orientacje teoretyczne: wczesne teorie zachowań zbiorowych, teorie mobilizacji zasobów, struktury możliwości politycznych i procesu politycznego, zwrotu kulturowego oraz nowych ruchów społecznych [Kowalewski 2016: 164-169]. Z uwagi na ograniczone ramy artykułu jestem zmuszony pominąć szczegółową analizę tej problematyki. Niemniej jednak konieczne jest dookreślenie kategorii ruchu społecznego. Powołując się na Piotra Sztompkę, będę wskazywać na dwie właściwości charakteryzujące ruchy społeczne. Po pierwsze, są one ukierunkowane na szczególny cel, jakim jest realizowanie jakiegoś rodzaju zmiany społecznej. Po drugie, przebiegają w ramach niezinstytucjonalizowanych i niesformalizowanych (a w każdym razie nie w pełni zinstytucjonalizowanych i sformalizowanych). W tym sensie są one czymś pośrednim między zachowaniami zbiorowymi (np. w tłumie) a działalnością zawodową (np. w urzędzie) [Sztompka 2005: 157-158].

Trudno jednoznacznie zdefiniować cel ruchów miejskich, gdyż, tak jak postaram się to pokazać w dalszej części, są one mocno zróżnicowane. Niemniej jednak w odniesieniu do ich genezy jako cel można wskazać ideę prawa do miasta. Zdaniem Przemysława Plucińskiego ideę prawa do miasta kojarzoną współcześnie przede wszystkim z Henrim Lefebvre'm można wynieść z klasycznych badań Fryderyka Engelsa nad warunkami życia angielskich robotników oraz procesami haussmannizacji Paryża [Pluciński 2014: 142]. W obu przypadkach mobilizacja społeczna nakładała się na konflikt klasowy rozgrywający się w przestrzeni miasta. Jedną $\mathrm{z}$ charakterystycznych cech rewolucji przemysłowej w jej początkowym okresie były fatalne warunki bytowe kształtującego się wielkoprzemysłowego proletariatu. Wiejscy migranci przybywający do miast pozbawiani podstawowych praw pracowniczych egzystowali w skrajnie złych warunkach mieszkaniowych. Kwestia mieszkaniowa i prawa pracownicze były zatem głównymi przyczynami formowania się tzw. starych ruchów społecznych, takich jak np. związki zawodowe. Natomiast za początek miejskich ruchów społecznych uznaje się często Komunę 
Paryską ${ }^{1}$ [Castells 1983]. W tym wypadku rozwój ruchów społecznych walczących o prawo do miasta był reakcją na modernizację Paryża, jakiej na polecenie Napoleona III dokonał Georges Haussmann w latach 1852-1870. Radykalna przebudowa miasta miała w pierwszej kolejności przeciwdziałać rewolucyjnym fermentom, których Paryż był prawdziwym epicentrum w tym okresie. Walter Benjamin, opisując przebudowę francuskiej stolicy, zwrócił uwagę, że „prawdziwym celem prac G. Haussmanna było zabezpieczenie miasta przed wojną domową. Chciał po wsze czasy uniemożliwić stawianie w Paryżu barykad" [Benjamin 2005: 44]. Przebudowa miasta miała tak zmienić jego tkankę, aby ograniczała ona możliwości miejskiej partyzantki i ułatwiała tłumienie zamieszek. W rzeczywistości przebudowa Paryża w istotny sposób zmieniła dotychczasowe stosunki społeczne w mieście. Przede wszystkim przyczyniła się do segregacji przestrzennej. Według Benjamina podnoszenie czynszów wypchnęło proletariat na przedmieścia, przez co dzielnice Paryża straciły swój specyficzny charakter. Powstała tzw. „czerwona obręcz". G. Haussmann odebrał paryżanom ich miasto [Benjamin 2005: 43]. Proletariat został wypchnięty na peryferia i zamknięty w lokalnych quartier, a centrum zdominowała mieszczańska klasa średnia. Richard Sennett podkreślił, że podczas przebudowy miasta przez G. Haussmanna celowo ograniczano mieszanie się klas w poszczególnych dzielnicach. Heterogeniczność, jaka spontanicznie zaistniała na skutek dzielenia prywatnych domów na mieszkania w pierwszej połowie XIX wieku, została teraz podważona, podjęto bowiem starania, by przekształcić dzielnice w homogeniczne jednostki ekonomiczne. Ekologia dzielnic jako ekologia klas - na tym polegał nowy mur wzniesiony przez G. Haussmanna między mieszkańcami miasta, a także wokół niego [Sennett 2009: 223-228]. Przebudowa Paryża stworzyła też nowy typ wielkomiejskiego, konsumpcyjnego aktora społecznego - flâneur, który nadwyżki swojego czasu i kapitału przeznaczał na konsumpcję miejskich atrakcji. Analizując skutki tak istotnych przemian tkanki miejskiej, David Harvey zwrócił uwagę, że system sprawdzał się bardzo dobrze przez około piętnaście lat i nie objął swoim zasięgiem jedynie transformacji infrastruktury miejskiej, ale też stworzył zupełnie nowy styl życia miejskiego i nowy rodzaj miejskiej mentalności. Paryż stał się „miastem świateł”, wielkim centrum konsumpcji turystyki i rozrywki: kawiarnie, domy towarowe, przemysł mody, wielkie wystawy - wszystko to zmieniło miejski styl życia, który mógł wchłonąć ogromne nadwyżki przez kompulsywny konsumpcjonizm. W konsekwencji w 1868 roku przerośnięty i coraz bardziej spekulacyjny system finansowy i kredytowy, na którym to wszystko było oparte, się załamał. G. Haussmann został usunięty z urzędu. Zdesperowany Napoleon III wyruszył na wojnę przeciw Niemcom Bismarcka i przegrał. W wytworzonej pustce zrodziła się Komuna Paryska, jeden z najwspanialszych rewolucyjnych epizodów w kapitalistycznej historii miast. Komunę powołano do życia częściowo z powodu nostalgii

1 Przyczyny wybuchu Komuny Paryskiej były oczywiście dużo bardziej złożone, a sam rozwój ruchów miejskich był raczej jedną z jej konsekwencji, a nie jedną z głównych przyczyn. 
za miejskim światem zniszczonym przez Haussmanna, a po części z pragnienia odzyskania swojego miasta, żywionego przez tych, którzy zostali przez prace modernizacyjne wywłaszczeni [Harvey 2012: 27]. Z czasem mit Komuny Paryskiej walczącej o prawo do miasta stał się ideą spajającą miejskie ruchy społeczne. Sama idea prawa do miasta została sformułowana w końcu lat 60. XX wieku przez Henriego Lefebvr'a [Lefebvr 2012], natomiast swoją aktualność zyskała zwłaszcza w dobie postępującej globalizacji i dominacji polityki neoliberalnej.

\section{WSPÓŁCZESNE MIEJSKIE RUCHY SPOŁECZNE}

Współczesne miejskie ruchy społeczne z uwagi na istotne procesy wywołane między innymi postępującą globalizacją i indywidualizacją przybierają specyficzną strukturę. Miasta intensywnie włączane w globalną sieć przepływów stają się coraz bardziej narażone na eksplorację globalnego kapitału. Tym samym coraz częściej stawiane są takie pytania, jak: czyje jest miasto? i co znaczy być dziś obywatelem miasta? [Sassen 2007: 2]. Dominacja globalnych przepływów: ludzi, idei, kapitałów, sprawia, że idea prawa do miasta zmienia swoje znaczenie, co podkreślał D. Harvey, pisząc, że „domaganie się prawa do miasta jest w efekcie żądaniem prawa do czegoś, co już dawno nie istnieje (jeśli kiedykolwiek istniało). Poza tym prawo do miasta jest pustym znaczącym. Wszystko zależy od tego, kto nadaje mu sens. Finansiści i deweloperzy mogą się go domagać i mają do tego wszelkie prawo. Ale z drugiej strony mogą to uczynić również bezdomni czy nielegalni imigranci. Nieuchronnie musimy zmierzyć się z pytaniem, czyje prawa zostają uznane w sytuacji, gdy, jak ujął to Marks w Kapitale: »między różnymi prawami rozstrzyga siła«" [Harvey 2012: 15]. W tym wypadku zmieniały się zasadniczo relacje w sferze władzy. To już nie burżuazja posiadająca środki produkcji dominuje nad pozbawionym ich proletariatem, ale globalne przepływy (kapitał) nad lokalnymi tożsamościami. Zatem istota konfliktu mobilizującego do działania dotyczy przede wszystkim kwestii związanych z podmiotowością i tożsamością miast. Zdaniem Alaina Touraine'a, jeśli centralnym konfliktem jest dziś ten, który przeciwstawia figury podmiotu potędze globalnego i bezosobowego systemu dominacji, lepiej mówić o ruchach kulturowych niż o ruchach społecznych. W dzisiejszym kontekście konflikt lub ruch społeczny może zatem wykształcić się i rozwinąć tylko wtedy, gdy jest w stanie interpretować odczucia subiektywne, a nie tylko dane ekonomiczne [Touraine 2011: 197-199]. Ową zmianę w mobilizację zasobów widać wyraźnie w przypadku przeobrażeń współczesnych miejskich ruchów społecznych, które tradycyjnie miały raczej lewicowy charakter i wyrastały z poczucia niesprawiedliwości społecznej. Obecnie zaczynają przybierać odmienny charakter, akcentują przede wszystkim kwestie kulturowe, a ich głównym aktorem staje się miejska klasa średnia [Della Porta, Diani 2009]. To sprawia natomiast, że główne konflikty społeczne rozgrywające się we współczesnych miastach nie są już, tak jak w epoce przemysłowej, 
determinowane dyskursem klasowym. Steven Buechler pisał: „Jeśli stare ruchy społeczne opierały się na solidnej bazie w postaci klasy robotniczej i ideologii, zakłada się, że nowe ruchy będą się wywodzić z innych klas społecznych. Nie ma jednak zgody co do tego, jak zdefiniować tę podstawę klasową, ani nawet, czy pojęcie klasy powinno pozostawać centralną kategorią w definiowaniu podstaw ruchu" [Buechler 2008: 175]. Współczesne ruchy miejskie, używając słów Becka, „wychodzą poza warstwę i klasę" [Beck 2002].

Ponadto rozwój nowych mediów, zwłaszcza takich jak internet, sprawił, że zmienia się struktura ruchów społecznych, które coraz częściej przybierają charakter amorficznych sieci. Manuel Castells, wskazując na przemiany struktury współczesnych ruchów społecznych, zwrócił uwagę, że ich podstawami są internet i sieci komunikacji mobilnej, ale ma ona charakter multimodalny. Obejmuje realne i wirtualne sieci społeczne, jak również sieci istniejące wcześniej oraz sieci, które powstały dzięki działaniom ruchu. Można wyróżnić sieci wewnątrz ruchu oraz sieci łączące ruch z innymi inicjatywami na całym świecie, z blogosferą internetową, mediami i opinią publiczną. Wprawdzie ruchy zwykle są zakorzenione w przestrzeni miejskiej przez okupację placów publicznych i demonstracje uliczne, ale jednocześnie stale istnieją $\mathrm{w}$ wolnej przestrzeni internetu. Jako sieć sieci mogą sobie pozwolić na brak wyraźnie określonego centrum, a mimo to koordynować działania i prowadzić dyskusje za pomocą interakcji między wieloma węzłami. Z tego powodu nie potrzebują formalnego przywództwa, ośrodków dowodzenia ani organizacji pionowej, żeby przekazywać informacje i instrukcje. Ta zdecentralizowana struktura maksymalizuje możliwości uczestnictwa w ruchu, ponieważ mamy do czynienia z sieciami otwartymi, bez wyraźnie zdefiniowanych granic [Castells 2013: 212]. Taka struktura z jednej strony zwiększa efektywność współczesnych ruchów społecznych, które łatwiej dostosowują się do zmieniającej się rzeczywistości. Z drugiej jednak stwarza istotne problemy metodologiczne dla ich badania, gdyż narzędzia badawcze nie zawsze nadążają za dynamiczną rzeczywistością.

Podobnie rzecz się ma z polskimi ruchami miejskimi, które jako stosunkowo nowy fenomen wymykają się tradycyjnym narzędziom służącym do operacjonalizacji zjawisk społecznych zachodzących w polskich miastach. Pluciński zwrócił uwagę, że „pojawienie się MRS [miejskich ruchów społecznych - przyp. P.K.] na scenie obywatelskiego aktywizmu zaskoczyło nieco samych socjologów. Szybko okazało się też, że próby opisu, tym bardziej zaś wyjaśnienia fenomenu MRS, stawiają pod znakiem zapytania klasyczne unarzędziowienie socjologiczne: zarówno dotyczące metody, jak i teorii” [Pluciński 2015: 412-413]. Starając się zatem analizować kwestię ruchów miejskich w Polsce, należy mieć świadomość zarówno przemian strukturalnych współczesnych ruchów społecznych, jak i problemów metodologicznych z tym związanych. 


\section{POLSKIE RUCHY MIEJSKIE}

Miejski aktywizm, rozumiany jako działalność na rzecz wspólnot lokalnych, nie jest w Polsce czymś zupełnie nowym. Jednak z uwagi na historyczne zaszłości wynikające $\mathrm{z}$ braku zainteresowania kwestią miejską nie miał on tak masowego charakteru jak ten kształtujący się na Zachodzie ${ }^{2}$. Od pewnego czasu możemy jednak obserwować, że także w Polsce rozproszone strategie aktywności społecznej na rzecz miasta zaczynają przybierać charakter ruchów społecznych. Tak jak w przypadku każdego ruchu społecznego ważną rolę odgrywają tu emocje. M. Castells, analizując procesy mobilizacji społecznej, zwrócił uwagę, że na poziomie indywidualnym ruchy społeczne to ruchy emocjonalne. Ich powstanie nie zaczyna się od stworzenia programu czy strategii politycznej. Mogą się one pojawić później, kiedy wewnątrz lub na zewnątrz ruchu wyłoni się przywództwo, żeby lansować strategie polityczne, ideologiczne i osobiste, które mogą - choć nie muszą - wiązać się z pierwotnym źródłem buntu i motywacjami członków ruchu. Dla ruchów społecznych najważniejszym momentem jest przekształcanie emocji w działanie [Castells 2013: 25-26]. W wypadku polskich ruchów miejskich emocje, które przekształcały się w działanie, miały dwojaki charakter. Z jednej strony wynikały z narastającej potrzeby kształtowania nowych miejskich narracji, na bazie których mogłyby się tworzyć emocjonalne więzi z miastem. Polski wzór kulturowy ukształtowany w procesie długiego trwania wykluczył miejskość z dominującego uniwersum symbolicznego. Konsekwencją tego był fakt, że brakowało atrakcyjnych narracji pobudzających emocjonalne więzi z miastem. Wraz z tworzeniem się nowego polskiego mieszczaństwa [Kubicki 2011], dla którego miejskość stawała się nadrzędnymi ramami odniesienia dla kształtowania nowych tożsamości, zaistniała potrzeba tworzenia takich narracji, które pobudzałyby emocjonalne związki z miastem. Z drugiej strony akcesja Polski do UE uruchomiła w Polsce wielki boom budowlany, który przy braku spójnych polityk miejskich [Gądecki, Kubicki 2014] naruszył, niejednokrotnie bardzo brutalnie, istniejącą tkankę społeczno-kulturową. Efektem tego było narastające poczucie frustracji spowodowanej bezsilnością obywateli w zetknięciu z bezdusznym kapitałem ingerującym w funkcjonowanie społeczności lokalnych.

Upraszczając nieco sprawę, można stwierdzić, że u podstaw polskich ruchów miejskich leżały dwie emocje: miłości (do miasta) i gniewu (niszczenie tradycyjnej tkanki miejskiej). Oba przypadki nakładają się na klasyczne typy ruchów miejskich opisanych przez M. Castellsa; oporu (gniew) i projektu (miłość). Ruchy oporu zdaniem kastylijskiego socjologa są tworzone przez tych aktorów, „którzy znajdują się w gorszym położeniu/warunkach dewaluowanych i/lub stygmatyzowanych przez logikę dominacji, a tym samym budują szańce oporu i przetrwania na podstawie zasad odmiennych od tych, które przenikają instytucje społeczeństwa" [Castells

2 Problem ten szczegółowo analizuję w mojej książce: Wynajdywanie miejskości. Polska kwestia miejska z perspektywy dtugiego trwania, Wydawnictwo Nomos, Kraków 2016. 
2008: 23]. Na polskim przykładzie były to najczęściej działania będące reakcją na chaos urbanistyczny będący konsekwencją rozmontowania regulacji prawnych dotyczących planowania przestrzennego, a także bezkrytyczną wiarą w politykę neoliberalną, w której ramach przestrzeń miasta była traktowana w czysto merkantylny sposób i miała w pierwszej kolejności generować zyski. Dlatego też, jak pisali autorzy Anty-bezradnika przestrzennego - prawo do miasta $w$ działaniu: „ruchy miejskie w całej swojej złożoności pojawiły się właśnie jako reakcja na »boom« inwestycyjny ostatniej dekady - a o ich zróżnicowaniu świadczy odmienny stosunek do tego fenomenu. Polskie ruchy miejskie pojawiły się na tej fali inwestycyjnej, która naruszyła tkankę miejską i, co za tym idzie, naruszyła także relacje społeczne, które w tej tkance były zawarte" [Mergler, Pobłocki, Wudarski 2013: 22]. Początkowo były to protesty przypominające zjawisko tzw. NIMBY (Not In My Back Yard), zorientowane na obronę własnych interesów i przerzucanie problemów na „podwórko" sąsiadów. Niektóre z tych grup protestu, widząc jednak, że problem ma charakter systemowy i doraźne protesty tego nie rozwiążą, zaczęły skupiać się w szerszych koalicjach, które wychodziły poza partykularne interesy. W ten sposób zaczął się tworzyć oddolny ruch społeczny zorientowany na obronę cennych miejskich zasobów: ładu przestrzennego i przyrody, szczególnie narażonych na destrukcyjny wpływ sił rynkowych. Przykładami takich procesów mogą być historie z Poznania i Krakowa. W obu miastach mobilizacja i integracja środowisk aktywistycznych w dużej mierze została zapoczątkowana jako reakcja na okrajanie miejskich terenów zielonych przez deweloperów. W miastach, które w ostatniej dekadzie przeżywały prawdziwy boom budowlany, konflikty dotyczące zabudowywanych terenów zielonych pojawiały się niemal w każdym fragmencie miasta. Początkowo mobilizacja społeczna miała jedynie charakter lokalny i trwała najczęściej nie dłużej niż sam konflikt, który ją spowodował. Kiedy jednak zagrożone stały się te tereny, które były uważane za najbardziej cenne przyrodniczo i rekreacyjne, rozproszone dotychczas środowiska zaczęły integrować się wokół wspólnego celu. W przypadku Poznania jednym z kilku pól konfliktów o przestrzeń, który doprowadził do integracji lokalnych ruchów miejskich, były protesty w obronie zabudowy dzielnicy Sołacz. Z uwagi na jej atrakcyjność położenia zaczęli się nią interesować deweloperzy, których ingerencja zniszczyłaby cenne przyrodniczo i krajobrazowo tereny [Mergler, Pobłocki, Wudarski 2013: 128-135]. To między innymi działania w obronie terenów zielonych postrzeganych jako cenny zasób miejski doprowadziły do zawiązania Stowarzyszenia My-Poznaniacy ${ }^{3}$, które zintegrowało rozproszoną dotychczas obywatelską energię poznańskich aktywistów miejskich.

3 Stowarzyszenie założone w 2007 r. było pierwszym ruchem miejskim, który wystartował w wyborach samorządowych w 2010 r., uzyskując poparcie na poziomie 9,36\%, co jednak, skutkiem ordynacji wyborczej preferującej duże byty polityczne, nie przełożyło się na żaden mandat w Radzie Miasta Poznania. W 2013 r. w efekcie wewnętrznych konfliktów wyodrębniły się dwie organizacje: My-Poznaniacy i Prawo do Miasta. 
W Krakowie natomiast przykładem takiej mobilizacji była obrona przed zabudową deweloperską bardzo popularnego wśród mieszkańców miasta terenu rekreacyjnego Zakrzówek. Atrakcyjne położenie sprawiło, że jedna z firm deweloperskich postanawiła zbudować tam duże osiedle bloków wielorodzinnych. Dla mieszkańców Krakowa była to przysłowiowa kropla przelewająca czarę goryczy. W mieście od lat zabudowywano różne skwery i tereny zielone, jednak dopiero możliwość zniszczenia tak cennego terenu, postrzeganego jako miejskie dobro wspólne, zmobilizowało tysiące krakowian do protestu przeciw planom budowy osiedla na Zakrzówku [Kubicki 2016]. W tym wypadku nie powstało sformalizowane stowarzyszenie, tak jak to miało miejsce w Poznaniu. Jednak doświadczenia wynikające ze wspólnych protestów, które ostatecznie przyniosły oczekiwane rozwiązania, pozwoliły na zbudowanie cennego kapitału społecznego, z którego korzysta wiele innych inicjatyw społecznych w Krakowie.

Drugim typem ruchów społecznych opisywanych przez M. Castellsa są ruchy projektu. Pojawiają się one, ,gdy aktorzy społeczni na podstawie dostępnych im materiałów kulturowych budują nową tożsamość, która redefiniuje ich pozycję w społeczeństwie, a czyniąc to, dążą do transformacji całej struktury społecznej" [Castells 2008: 22]. W Polsce ruchy projektu stały się kluczowymi agentami zmiany kulturowej, dostarczają nowych miejskich narracji pozwalających przełamać dominujący dyskurs, w ramach którego miasto było sprowadzane jedynie do sumy prywatnych własności. Tworzone przez nie narracje i podejmowane działania dają podstawy do spojrzenia na miasto jak na dobro wspólne. Geneza tych ruchów jest powiązana z rozwojem i przeobrażeniami sfery internetu. Upraszczając sprawę, chodzi tu o sytuację, w której internet zaczął być wykorzystywany już nie tylko do zdobywania i wymiany informacji, lecz także do budowania kapitału społecznego. W tym wypadku ważną rolę odegrało Forum Polskich Wieżowców skupiające tysiące internautów zainteresowanych kwestiami miejskimi. FPW powstałe w 2002 r., jako polska wersja globalnego forum SkyscrapesCity, stało się prawdziwą agorą, gdzie deliberowano polską kwestię miejską [Kubicki 2013]. Wiele z obecnie działających ruchów miejskich, posiadających także oficjalne struktury, początkowo funkcjonowało jako internetowe kluby dyskusyjne na FPW. Zupełnie nową jakością okazał się być rozwój portali społecznościowych, zwłaszcza takich jak Facebook, który stał się inkubatorem aktywności społecznej, nie tylko w przypadku polskich ruchów miejskich. Zdaniem Castellsa współczesna przestrzeń internetu otworzyła nowe możliwości dla aktywności społecznej, tworząc alternatywą przestrzeń komunikacji. Analizując współczesne ruchy społeczne, kastylijski socjolog pisał o nich, że wszystko zaczęło się w internetowych serwisach społecznościach, ponieważ jest to przestrzeń autonomii pozostająca w dużej mierze poza kontrolą rządów i korporacji, które wcześniej zmonopolizowały kanały komunikacji i uczyniły je fundamentem swojej władzy. Hybryda cyberprzestrzeni i przestrzeni miejskiej tworzy trzecią przestrzeń - przestrzeń autonomii. Autonomia istnieje tylko wówczas, gdy ludzie mogą się zorganizować w wolnej przestrzeni sieci komunikacyjnych, ale stają się 
siłą transformacyjną dopiero wtedy, gdy ludzie rzucą wyzwanie instytucjonalnemu porządkowi dyscyplinarnemu i odzyskają przestrzeń miasta dla jego mieszkańców. „Przestrzeń autonomii to nowa przestrzenna forma usieciowionych ruchów społecznych" [Castells 2013: 14, 213]. Główny nurt polskiej kultury długo był pozbawiony atrakcyjnych narracji, dzięki którym mogłyby się kształtować emocjonalne więzi mieszkańców z ich miastami. Rozwój autonomicznej sfery internetu otworzył możliwości kształtowania nowych, alternatywnych miejskich narracji, które z czasem dzięki zasobom symbolicznym aktywistów zaczęły przenikać do głównego dyskursu [Kubicki 2016].

\section{TOŻSAMOŚĆ POLSKICH RUCHÓW MIEJSKICH}

Opisane powyżej modele należy traktować jako Weberowskie typy idealne. W praktyce często nakładają się na siebie. Niezależnie jednak od klasyfikacji i genezy aktywizm miejski w Polsce zaczął przybierać znamiona ruchu społecznego o wykrystalizowanej i silnej tożsamości. Proces konstruowania tożsamości kolektywnych jest zjawiskiem złożonym i rozciągniętym w czasie. Upraszczając jednak sprawę, można założyć, że będzie się on składał z trzech zasadniczych faz.

Po pierwsze, konieczne jest stworzenie symbolicznych granic, które pozwolą odróżnić się danej grupie od innych, czego jednym z najbardziej oczywistych przykładów jest przyjęcie wspólnej podzielanej nazwy. Trudno jednoznacznie określić, kiedy w środowisku miejskich aktywistów zaczęła się kształtować świadomość tworzenia ruchu społecznego wykraczającego poza partykularne, lokalne problemy. Można jednak z dużym prawdopodobieństwem postawić hipotezę, że działo się to na przełomie 2010 i 2011 roku. W 2010 roku odbyły się w Łodzi, a później w Lublinie, ogólnopolskie spotkania aktywistów miejskich pod nazwą „Wspólna przestrzeń”. W trakcie debat i prezentacji swoich działań nie używano sformułowania „ruch miejski”. Natomiast w czerwcu 2011 roku znakomita większość tych samych osób obradujących na I Kongresie Ruchów Miejskich w Poznaniu nie miała już wątpliwości, że tworzy miejskie ruchy społeczne.

Drugą fazą jest tworzenie instytucji, które będą w stanie krystalizować wizerunek wspólnoty. W tym wypadku kluczową rolę odegrał Kongres Ruchów Miejskich. Formalnie KRM zawiązał się w Poznaniu w czerwcu 2011 roku. Jak do tej pory odbyły się cztery kongresy, poza pierwszym w Poznaniu: II KRM w Łodzi (2012), III KRM w Białymstoku (2013) i IV KRM w Gorzowie Wielkopolskim (2015), V odbył się w maju 2016 w kilku miastach Śląska i Zagłębia. Integracja w ramach KRM przyczyniła się do kształtowania się pewnej wspólnoty ideologicznej, będącej ważnym spoiwem dla tożsamości kolektywnych. Miejscy aktywiści, podkreślając swoją apolityczność i brak ideologicznego dogmatyzmu, zgodzili się co do swoistego minimum, określającego tożsamość miejskiego ruchu społecznego. Tym minimum stało się 9 Tez Miejskich wypracowanych na pierwszym KRM w Poznaniu (po IV KRM 
w Gorzowie Wielkopolskim w 2015 roku jest to 15 Tez Miejskich). Na bazie Tez Miejskich sformułowano tzw. ,miastopogląd”, stanowiący spoiwo ideologiczne ruchu miejskiego. Zdaniem liderów tego ruchu, miastopogląd „ma swoją podstawową aksjologię: sprawiedliwy i demokratyczny rozwój zrównoważony miasta, tradycja praw i wolności człowieka i obywatela, tradycje demokracji. Ruchy miejskie nie skupiają rewolucjonistów, których celem jest obalenie systemu polityczno-społecznego, ale mniej lub bardziej radykalnych reformatorów systemu. Owa reforma nie jest wymyślona czy zaplanowana »odgórnie«, lecz wychodzi od konkretów, w których naocznie stwierdzamy dysfunkcjonalność systemu lub jego fragmentów. Opierają się one na polskim i europejskim prawie, wolnościowej oraz demokratycznej tradycji, które traktuje się nie jako »dekorację«, lecz bardzo serio. Stąd znaczenie partycypacji społecznej, łączenia form demokracji bezpośredniej i uczestniczącej, których głównym celem jest rzeczywiste współdecydowanie o mieście, czyli egzekwowanie prawa do miasta" [Mergler, Pobłocki, Wudarski 2013: 38-39]. Tak definiowany miastopogląd, dzięki stosunkowo szerokiemu zakresowi semantycznemu, potrafił połączyć wiele różnych organizacji, których członkowie reprezentują często bardzo odmienne postawy światopoglądowe. Joanna Erbel, socjolożka i jedna z liderek tego ruchu, zwróciła uwagę, że ruchy miejskie, postulując tzw. „narrację konkretną”, koncentrowały się zwykle na bieżących sprawach do załatwienia, które gromadziły we wspólnym działaniu osoby, zwykle niemające okazji się spotkać oraz między którymi nieraz istniały istotne różnice światopoglądowe - lewicowe feministki, anarchiści, konserwatywni działacze, uczestniczki demonstracji pro-life i wiele innych osób. Zgromadzenie we wspólnym działaniu tak różnorodnej grupy było możliwe dzięki skupieniu się na tym, co tu i teraz jest do załatwienia w mieście i co ma niewiele wspólnego ze sporami odbywającymi się na poziomie polityki ogólnokrajowej [Erbel 2014: 42]. Z kolei Pluciński pisał, że „najsilniejszym bodaj kryterium identyfikacji MRS (miejskie ruchy społeczne - przyp. P.K.), pozwalającym traktować je na gruncie socjologicznych teorii ruchów społecznych jako odrębny fenomen, pozostaje względnie spójny kontekst ideowy, do którego się odwołują. Idzie przede wszystkim o idee prawa do miasta, demokracji miejskiej (urban democracy) oraz niekiedy sprawiedliwości przestrzennej (spatial justice). Stanowią one przy tym nie tylko narzędzia opisu rzeczywistości, ale przede wszystkim instrumenty skutecznego działania. To właśnie one, przede wszystkim ich historycznie określona zmienność oraz praktyki interpretacyjne wytwarzają MRS jako relatywnie jednolity, z całym wewnętrznym zróżnicowaniem, podmiot miejskiej zmiany i hybrydową tożsamość polityczną ruchów, przez którą rozumiem procesy autodefinicyjne polegające na budowaniu wewnętrznej spójności, konstruowaniu »ideologicznego my« rozmaitych frakcji MRS" [Pluciński 2015: 415-416].

Mimo różnorodności światopoglądowej cechującej członków KRM współpraca w jego ramach trwa już od kilku lat i coraz bardziej się zacieśnia. Na IV KRM we wrześniu 2015 roku odbywającym się w Gorzowie Wielkopolskim podjęto decyzję o przekształceniu KRM w formalną strukturę posiadającą podmiotowość prawną, któ- 
rej KRM do tej pory nie posiadał. Ostatecznie w maju 2016 roku powołano do życia Związek Stowarzyszeń Kongres Ruchów Miejskich. W podsumowaniu IV KRM jeden z liderów tego ruchu - Lech Mergler - pisał, że ,jedną z naszych istotnych wartości, które były widoczne w Gorzowie, jest pluralizm, wewnętrzne zróżnicowanie (w dających się »skonsumować« granicach) - polityczne, światopoglądowe, ideologiczne, będące naszym zasobem i bogactwem. Jego utrzymanie jest możliwe dzięki pewnej wewnętrznej samodyscyplinie związanej ze zgodą na minimum samoograniczenia dla wspólnego działania, współpracy. Nie jest to częste, więc tym bardziej cenne i wymagające zachowania. Wewnętrzne zróżnicowanie, odmienności, które się wzajemnie równoważą (np. wielopartyjni, bezpartyjni i antypartyjni), odpowiada zrównoważonej, intuicyjnej strategii rozwoju KRM, nie wolnej od potknięć, ale trwającej już piąty rok. Taki wzrost pozwalający zachować tożsamość Kongresu w warunkach znacznych napięć polityczno-społecznych w jego otoczeniu trzeba kontynuować. Jego intencją powinno być budowanie (przez rośnięcie) siły społecznej i politycznej (w rozumieniu wspólnego »miastopoglądu«, a nie jakiejś perspektywy partyjnej), zdolnej coraz bardziej skutecznie zawalczyć o nasze miasta” [Mergler 2015].

Trzecią fazą kształtowania tożsamości kolektywnych jest uznanie, rozpoznanie przez partnerów, z którymi wchodzi się w interakcje społeczne. Często problemem jest tzw. błędne uznanie [Taylor 2011], kiedy partnerzy usytuowani wyżej w strukturze władzy narzucają obraz danej grupy niezgodnie z jej oczekiwaniami. Podobnie działo się w wypadku polskich ruchów miejskich, które jak każdy ruch społeczny w momencie formowania się podlegały procesowi stereotypizacji. Działalność ruchów miejskich, która była coraz bardziej zauważalna, stała się przedmiotem ożywionych publicystycznych dyskusji. Te jednak bardziej sprzyjały kształtowaniu fałszywych stereotypów niż rzeczowej analizie nowego zjawiska. W pewnym uproszczeniu można wskazać dwa zasadnicze stereotypy, za pomocą których w dyskursie medialnym opisywano miejskich aktywistów. Z jednej strony byli oni opisywani jako „pieniacze” protestujący w celu realizacji własnych egoistycznych celów blokujących ważne miejskie inwestycje. Z drugiej strony natomiast, jako zblazowana wielkomiejska inteligencja zapełniająca modne klubokawiarnie, której działalność obywatelska sprowadza się jedynie do aktywności na popularnych portalach społecznościowych.

Istotna zmiana w tym zakresie zaczęła zachodzić od 2014 roku, na co zasadniczy wpływ miały dwa wydarzenia. Po pierwsze, krakowski ruch miejski Kraków Przeciw Igrzyskom zdołał doprowadzić do referendum, w którym mieszkańcy Krakowa opowiedzieli się przeciwko współorganizacji przez miasto Zimowych Igrzysk Olimpijskich. Pomimo intensywnej kampanii reklamowej ZIO i zaangażowania głównych podmiotów politycznych referendum okazało się spektakularną porażką potencjalnych organizatorów ZIO. Frekwencja w referendum wyniosła 35,96\%, z czego 69,72\% głosujących opowiedziało się przeciw organizacji ZIO w Krakowie. Skutkiem referendum była wyraźna zmiana publicznego dyskursu, w którego ramach przedstawiano dotychczas ruchy miejskie. Ruchy miejskie zyskały „uznanie” jako realna siła zdolna do kształtowania nowego języka debaty o mieście, a także siła 
potrafiąca mobilizować znaczne zasoby ludzkie do podejmowania realnych działań w przestrzeni miejskiej.

Drugim wydarzeniem były wybory samorządowe odbywające się jesienią 2014 roku, przy okazji których zawiązała się koalicja wyborcza Porozumienie Ruchów Miejskich. PRM tworzyło jedynie 9 organizacji, z czego część z nich miała z miejskimi ruchami społecznymi niewiele wspólnego, były to typowe obywatelskie komitety wyborcze. Poza spektakularnym sukcesem w Gorzowie Wielkopolskim, gdzie ruch miejski Ludzie dla Miasta osiągnął drugi wynik wyborczy, wprowadzając siedmiu radnych do dwudziestopięcioosobowej Rady Miasta, a jego kandydat Jacek Wójcicki wygrał wybory prezydenckie, PRM nie odniosło większego sukcesu wyborczego. To jednak nie kwestie mandatów w radach miast były najważniejsze. Ruchy miejskie dzięki kampanii wyborczej potrafiły wprowadzić do dyskursu publicznego nowy język debaty o mieście. Co istotne, to właśnie ten język zaczął się stawać dominującym dyskursem interpretacyjnym, który zdaniem Alaina Touraine'a stanowi zespół przedstawień, wyobrażeń stanowiący instancję pośredniczącą, odpowiedzialną przede wszystkim za konstrukcję obrazu całości życia społecznego i doświadczenia jednostki, gdzie na pośredniczącym poziomie dyskursu ideologicznego dokonują się wybory intelektualne i wykluwają warunki komunikacji, które narzucają reguły gry, przyznają tym, a nie innym przywilej bycia słuchanym [Touraine 2011: 31-32]. Miejscy aktywiści dzięki integracji w ramach miejskich ruchów społecznych zyskali przywilej bycia słuchanym, a dzięki rosnącym zasobom symbolicznym są w stanie kształtować nowy dyskurs myślenia i mówienia o mieście.

\section{ZAKOŃCZENIE}

Ruchy społeczne należy postrzegać jako nieustanny proces. Formują się jako luźne grupy poza oficjalnymi strukturami, aby z czasem stać się immanentną częścią systemu. Tak działo się z tzw. starymi ruchami społecznymi z XIX wieku, jak np. związki zawodowe, które $\mathrm{z}$ oddolnego ruchu społecznego stały się z czasem ważnym elementem systemu społecznego świata Zachodu. Podobnie działo się z tzw. nowymi ruchami społecznymi formującymi się w drugiej połowie XX wieku, jak np. ruch ekologiczny. Także i one stanowią dziś ważną część oficjalnego sytemu. Zapewne także i polskie ruchy miejskie przejdą taką drogę. Symptomy tego są już zresztą obserwowane. W niektórych miastach (Poznań, Słupsk) postulaty ruchów miejskich są realizowane przez urzędujących prezydentów. W innych miastach (Łódź, Lublin) miejscy aktywiści wsparli swoją wiedzą i doświadczeniem struktury urzędu miejskiego, stając się etatowymi pracownikami magistrackich wydziałów. Wspomniane przykłady to jednak wyjątki, w znakomitej większości polskich miast ich zarządzanie ma niewiele wspólnego $\mathrm{z}$ realizacją postulatów zrównoważonego rozwoju. Dlatego też ruchy miejskie jeszcze długo będą funkcjonować jako ruchy społeczne i wypełniać rolę czwartej władzy. To na nich spoczywać będzie rola 
prowadzenia konstruktywnej krytyki złych polityk miejskich. Jednocześnie coraz bardziej profesjonalizujące się środowiska ruchów miejskich będą stanowić swoiste think tanki dostarczające innowacji społecznych w sferze zarządzania miastami.

\section{BIBLIOGRAFIA}

Beck, U. 2002. Społeczeństwo ryzyka. W drodze do innej nowoczesności, Wydawnictwo Naukowe Scholar, Warszawa.

Benjamin, W. 2005. Pasaże, Wydawnictwo Literackie, Kraków.

Buechler, S.M. 2008. Teorie nowych ruchów społecznych. Dynamika życia społecznego, [w:] Wspótczesne koncepcje ruchów społecznych, K. Gorlach, P. Mooney (red.), Wydawnictwo Naukowe Scholar, Warszawa.

Castells, M. 2013. Sieci oburzenia i nadziei. Ruchy społeczne w erze Internetu, Wydawnictwo Naukowe PWN, Warszawa.

Castells, M. 2007. Spoleczeństwo sieci, Wydawnictwo Naukowe PWN, Warszawa.

Castells, M. 1983. The City and the Grassroots: A Cross-cultural Theory of Urban Social Movements, University of California Press, Berkeley.

Della Porta, D., Diani, M. 2009. Ruchy społeczne. Wprowadzenie, Wydawnictwo Uniwersytetu Jagiellońskiego, Kraków.

Gądecki, J., Kubicki, P. 2014. Polityki miejskie, „Politeja. Pismo Wydziału Studiów Międzynarodowych i Politycznych UJ", nr 27.

Harvey, D. 2012. Bunt miast. Prawo do miasta i miejska rewolucja, Wydawnictwo Bęc Zmiana, Warszawa.

Erbel, J. 2014. Ruchy miejskie jako nowa forma zaangażowania społecznego, „Władza Sądzenia. Rozważania o kulturze politycznej”, nr 4, dostępny na: www.wladzasadzenia.pl

Lefebvre, H. 2012. Prawo do miasta, „Praktyka Teoretyczna”, nr 5.

Kowalewski, M. 2016. Protest miejski. Przestrzenie, tożsamości i praktyki niezadowolonych obywateli miast, Wydawnictwo Nomos, Kraków.

Kubicki, P. 2016. Wynajdywanie miejskości. Polska kwestia miejska z perspektywy dlugiego trwania, Wydawnictwo Nomos, Kraków.

Kubicki, P. 2013. Polskie ruchy miejskie in statu nascendi, [w:] Partycypacja obywatelska - decyzje bliższe ludziom, A. Maszkowska, K. Sztop-Rutkowska (red.), Fundacja Laboratorium Badań i Działań Społecznych „SocLab”, Białystok.

Kubicki, P. 2011. Nowi mieszczanie - nowi aktorzy na miejskiej scenie, „Przegląd Socjologiczny”, t. LX/2-3.

Mergler, L. 2015. Co nam po IV Kongresie Ruchów Miejskich, http://zielonewiadomosci.pl/tematy/miasto-2/ co-nam-po-iv-kongresie-ruchow-miejskich/ (dostęp: 03.11.2015).

Mergler, L., Pobłocki, K., Wudarski, M. 2013. Anty-bezradnik przestrzenny-prawo do miasta w dziataniu, Res Publica Nowa, Warszawa.

Pluciński, P. 2015. Im lepiej, tym gorzej albo widmo kryzysu miejskich ruchów społecznych?, „Ruch Prawniczy, Ekonomiczny i Socjologiczny", r. LXXVII, z. 1.

DOI: https://doi.org/10.14746/rpeis.2015.77.1.23.

Pluciński, P. 2014. „Miasto to nie firma!” Dylematy i tożsamość polityczna miejskich ruchów społecznych we wspótczesnej Polsce, „Przegląd Socjologiczny”, t. LXIII/1.

Sassen, S. 2007. Globalizacja. Esej o nowej mobilności ludzi i pieniędzy, Wydawnictwo Uniwersytetu Jagiellońskiego, Kraków.

Sennett, R. 2009. Upadek czlowieka publicznego, Wydawnictwo Muza, Warszawa.

Sztompka, P. 2005. Socjologia. Analiza spoteczeństwa, Wydawnictwo Znak, Kraków.

Touraine, A. 2011. Myśleć inaczej, Państwowy Instytut Wydawniczy, Warszawa.

Taylor, C. 2001. Źródła podmiotowości: narodziny tożsamości nowoczesnej, Wydawnictwo Naukowe PWN, Warszawa. 
FROM URBAN SOCIAL ACTIVISM TO URBAN SOCIAL MOVEMENTS

Abstract: The article concerns the problem of the processes of the formation and development of Polish urban social movements. In the first part of the article, the author analyses historical background of urban social movements in Europe and structural changes among contemporary social movements. The second part is devoted to the specificity of social activism in Polish cites. The author analyses the transformation processes of dispersed urban social activism into urban social movement, represented by such organization as the Congress of Urban Movements as well as the electoral coalition: the Alliance of Urban Movements.

Keywords: social movements, urban movements, city, urbanity, Poland

\section{BIOGRAM}

Pawel Kubicki, socjolog i antropolog kultury. Adiunkt w Instytucie Europeistyki Uniwersytetu Jagiellońskiego w Krakowie. Kontakt e-mail: pawel.kubicki@uj.edu.pl. 